\title{
X-chromosome inactivation in the human trophoblast of early pregnancy
}

\begin{abstract}
To investigate X-chromosome inactivation (XCI) in human trophoblasts during early pregnancy, trophoblast genomic DNA was extracted and analyzed for a Bst XI restriction endonuclease site polymorphism in the $\mathrm{X}$-linked phosphoglycerate kinase gene, after digestion with methylation-sensitive Hpa II (control samples were digested instead with $A f a I$ ). Six villous trophoblast DNA samples were informative for the polymorphism (ie, heterozygous) and were derived from women homozygous for the polymorphism. These samples were then evaluated for XCI. In five of the six samples with Hpa II predigestion, the sizes of the two heterozygous band peaks differed; maternal $\mathrm{X}$-chromosome $\left(\mathrm{X}^{\mathrm{M}}\right)$-derived alleles showed smaller peak sizes than paternal $\mathrm{X}$-chromosome $\left(\mathrm{X}^{\mathrm{P}}\right)$-derived alleles, but the differences varied in degree. In samples obtained by microdissection from formalin-fixed, paraffin-embedded tissues (30 samples from different anchoring villi, and 38 samples from different branch villi), monoclonal band patterns of $\mathrm{X}^{\mathrm{P}}$-derived alleles were observed more frequently than those of $\mathrm{X}^{\mathrm{M}}$-derived alleles, but almost half of the samples showed polyclonal patterns. Our results suggest that a skewing of XCI exists in the human trophoblast; however, the degree of nonrandomness due to predominant $\mathrm{X}^{\mathrm{P}}$ inactivation appears to be restricted. It is probable that transcription of the $\mathrm{X}$ inactivation center $(X I C)$ begins earlier in mice than in humans.
\end{abstract}

Key words Extra-embryonic tissue $\cdot$ Methylation-sensitive endonuclease $\cdot$ Phosphoglycerate kinase $\cdot$ RFLP $\cdot$ Skewing of X-chromosome inactivation

S. Uehara $(\varangle) \cdot$ M. Tamura $\cdot$ N. Yaegashi $\cdot$ K. Okamura $\cdot$ A. Yajima Department of Obstetrics and Gynecology, Tohoku University School of Medicine, 1-1 Seiryo-machi, Aoba-ku, Sendai 980-8574, Japan

Tel. +81-22-717-7251; Fax +81-22-717-7258

e-mail: uehara@ob-gy.med.tohoku.ac.jp

M. Nata $\cdot$ G. Ji

Department of Forensic Medicine, Tohoku University School of Medicine, Sendai 980-8574, Japan

\section{Introduction}

Lyon (1961) identified the phenomenon of X-chromosome inactivation (XCI) in female mammals, such that one of the two $\mathrm{X}$-chromosomes is randomly inactivated to compensate for the difference in X-linked gene dosage between males and females. XCI occurs in a developmentally regulated manner that coincides with cellular differentiation from the late morula through to the blastocyst stage (Tan et al. 1993). Thereafter, XCI is generally stable throughout subsequent cell divisions (Heard et al. 1997).

In mice, embryonic tissues show symmetric XCI, that is, there is an equal chance of either the paternal or maternal $\mathrm{X}$-chromosome (abbreviated as $\mathrm{X}^{\mathrm{P}}$ and $\mathrm{X}^{\mathrm{M}}$, respectively) being inactivated in a given cell. By contrast, trophectoderm and primitive endoderm, which differentiate to extra-embryonic tissues, including the chorion, show asymmetric XCI in which $\mathrm{X}^{\mathrm{P}}$ is preferentially inactivated (Takagi et al. 1978; West et al. 1977; Harper et al. 1982). Preferential XCI in these tissues appeared to result from genomic imprinting mediated by Xist, a candidate gene for XCI (Brown et al. 1991; Heard et al. 1997; Goto and Monk 1998). However, the XCI state in the human chorion is more controversial.

Migeon and Do (1979), Migeon et al. (1985), and Mohandas et al. (1989) studied glucose-6-phosphate dehydrogenase (G6PD) isozymes and observed random XCI in chorionic villi from early gestation. Likewise, Bamforth et al. (1996) analyzed the methylation status at the DXS255 locus and demonstrated predominantly symmetric XCI. In contrast, reports that examined G6PD isozymes (Harrison and Warburton 1986; Harrison 1989) or the methylation status of the androgen receptor gene (Goto et al. 1997), found preferential $\mathrm{X}^{\mathrm{P}}$ inactivation in chorionic villi from early pregnancy. Moreover, Looijenga et al. (1999) reported that trophoblasts from full-term placentas showed no preferential XCI, whereas Ropers et al. (1978) determined that $\mathrm{X}^{\mathrm{P}}$ was preferentially inactivated.

Allelic methylation is thought to play an important role in XCI (Razin and Riggs 1980; Monk 1986; Mohandas et al. 1989). Approximately $70 \%$ of 5'CpGs are methylated 
in an inactivated X chromosome (Bird 1986), and almost all $\mathrm{CpGs}$ in $\mathrm{CpG}$ islands of the $\mathrm{X}$-linked phosphoglycerate kinase gene $(P G K)$ are methylated on the inactive $\mathrm{X}$-chromosome and hypomethylated on the active $\mathrm{X}$-chromosome (Pfeifer et al. 1990). Thus, the pattern of XCI can be examined by assessing differential methylation between the active and inactive $\mathrm{X}$ chromosomes via methylationsensitive endonuclease treatment (Vogelstein et al. 1987). Some groups have described methylation-specific polymerase chain reaction (PCR) methods which depend on the $P G K$ Bst XI polymorphism for clonality analyses (Gilliland et al. 1991; van Kamp et al. 1991; Shroyer and Gudlaugsson 1994; Kawai et al. 1995). In the current study, we quantitatively analyzed a Bst XI restriction fragment length polymorphism (RFLP) pattern of $P G K$ after performing methylation-specific PCR on DNA samples derived from branch-villi formed by syncytiotrophoblasts and cytotrophoblasts (syncytiotrophoblasts being the differentiated derivatives of cytotrophoblasts) (Yoshida 1964). Furthermore, to evaluate the XCI status in detail, microdissected trophoblasts obtained separately from anchoring and branch villi were analyzed for their XCI clonality by the same methods, except for the use of nested PCR. Trophoblasts that form anchoring villi, which connect branch villi to the decidua, are cytotrophoblast derivatives (intermediate trophoblasts) (Kurman et al. 1984).

\section{Materials and methods}

\section{Materials}

Samples of uterine contents at the seventh to eighth week of gestation were obtained from 46 women who underwent dilatation and curettage for elective abortion. Fresh branch villi were obtained from villous chorion and washed three times vigorously in phosphate-buffered saline, and trophoblastic tissues were mechanically separated from connective tissues under a dissecting microscope (Goto et al. 1997). The remaining villous chorion and decidua were fixed separately in $10 \%$ buffered neutral formalin and embedded in paraffin. Maternal peripheral blood samples were obtained simultaneously with the samples of uterine contents, with a heparinized syringe, and used for DNA extraction. Samplings were taken after obtaining fully informed consent from the women. The research protocol was approved by the Human Research Board of the Ethics Committee of Tohoku University School of Medicine.

\section{Karyotypic analysis of trophoblasts}

Fresh trophoblasts from branch villi were minced and cultured in Chang media (Irvine Scientific, Santa Ana, CA, USA) in $5 \% \mathrm{CO}_{2}$ at $37^{\circ} \mathrm{C}$ for 2 weeks. Proliferating trophoblasts were treated with colcemid for $4 \mathrm{~h}$ and harvested. Cells were treated with hypotonic $\mathrm{KCl}$ and fixed in Carnoy's solution. Suspensions were mounted on glass slides and dried, and CTG-banding was performed (Seabright 1971). Twenty or more metaphases were analyzed for each sample.

Bst $X I$ polymorphism in $P G K$ in branch-villous trophoblasts and peripheral blood

Genomic DNA was extracted from fresh branch-villous trophoblasts and maternal peripheral blood samples, using SepaGene (Sanko Junyaku, Tokyo, Japan), and stored at $-20^{\circ} \mathrm{C}$. When branch villous samples were karyotyped as $46, \mathrm{XX}$, the trophoblast DNA samples were processed alongside the maternal blood samples for preliminary determination of the PGK Bst XI polymorphism.

DNA samples $(0.2 \mu \mathrm{g})$ were subjected to PCR in a total volume of $50 \mu \mathrm{l}$ containing $5 \mu \mathrm{l} 10 \times$ PCR buffer, including $15 \mathrm{mM} \mathrm{MgCl}_{2}$ (Takara Shuzo, Otsu, Japan), $5 \mu \mathrm{dNTP}$ (Takara Shuzo), $1 \mathrm{mM}$ forward primer (5'-AGCTGGACGTTAAAGGGAAGC-3') (primer $2 \mathrm{~F}$ in Fig. 1 ), $1 \mathrm{mM}$ reverse primer (5'-TAGTCCTGAAGTTAAATCAAC$3^{\prime}$ ) (primer $2 \mathrm{R}$ in Fig. 1), and $0.625 \mathrm{U}$ DNA polymerase (Takara Shuzo). After an initial incubation of $5 \mathrm{~min}$ at $94^{\circ} \mathrm{C}$, reactions were cycled for $1 \mathrm{~min}$ at $94^{\circ} \mathrm{C}, 1 \mathrm{~min}$ at $56^{\circ} \mathrm{C}$, and $1 \mathrm{~min}$ at $72^{\circ} \mathrm{C}$ for 33 cycles in a TaKaRa PCR Thermal Cycler MP (Takara Shuzo). Aliquots of the PCR products $(5 \mu \mathrm{l})$ were digested with $30 \mathrm{U}$ of the restriction endonuclease Bst XI (Toyobo, Tokyo, Japan) for $12 \mathrm{~h}$ at $50^{\circ} \mathrm{C}$. The reaction was terminated by heating at $65^{\circ} \mathrm{C}$ for $20 \mathrm{~min}$, after which the resultant DNA fragments were electrophoresed in $2 \%$ agarose gels and stained with ethidium bromide. The schematic sequence of the $P G K$

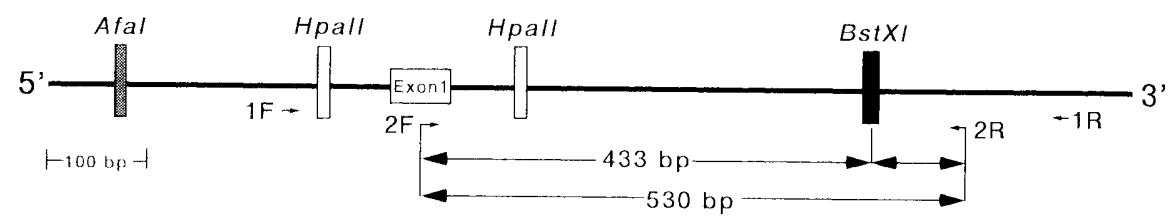

Fig. 1. Schematic diagram showing endonuclease sites, locations of polymerase chain reaction (PCR) primers, and sizes of the amplified and digested fragments of the phosphoglycerate kinase gene $(P G K)$. A $530-\mathrm{bp}$ band is derived from alleles without the Bst $X I$ site, and 433- and 97-bp bands from alleles with the Bst XI site (as determination of the 97-bp band was unnecessary, it is not referred to in this study). In females heterozygous for the Bst $X I$ polymorphism, polyclonal tissue generates two bands (530 and $433 \mathrm{bp}$ ). However, if tissue is monoclonal, Нpa II digestion yields a single band of either 530 or $433 \mathrm{bp}$. Therefore, the determination of clonality requires that samples be heterozygous for the $P G K B$ st $X I$ polymorphism 
gene is shown in Fig. 1 with the primer and endonuclease sites (Michelson et al. 1985).

\section{XCI determination in branch villous trophoblasts}

Branch villous trophoblast samples that were heterozygous for the Bst XI polymorphism and were obtained from mothers homozygous for the polymorphism were considered informative for XCI status.

DNA samples $(1 \mu \mathrm{g})$ obtained from branch-villous trophoblasts were incubated for $12 \mathrm{~h}$ at $37^{\circ} \mathrm{C}$ in a total volume of $50 \mu \mathrm{l}$ with $30 \mathrm{U}$ methylation-sensitive restriction endonuclease Hpa II (Takara Shuzo) to completely digest nonmethylated (active) alleles. Reactions were terminated by heating at $65^{\circ} \mathrm{C}$ for $20 \mathrm{~min}$. Duplicate (control) samples were identically incubated with $A f a I$ (Takara Shuzo) which did not cut amplification loci and enabled amplification from a small amount of DNA (Nomura et al. 1996). After the predigestion, $5 \mu \mathrm{l}$ DNA samples were amplified by PCR, using the same conditions as described above except that the forward primer was labeled with 6-FAM (carboxyfluorescein). Aliquots of the PCR products $(5 \mu \mathrm{l})$ were digested with Bst $X I$ and subjected to denaturing polyacrylamide gel electrophoresis. Heterozygous twoband patterns were detected using a 377 DNA sequencer (Perkin-Elmer, Foster City, CA, USA), and peak heights and areas were measured using GeneScan Analysis 2.0.2 software (Perkin-Elmer). The procedures were performed at least twice in separate experiments.

\section{Evaluation of XCI status in anchoring and branch villi}

To evaluate XCI clonality, trophoblast samples were microdissected from formalin-fixed, paraffin-embedded uterine contents of the same six women as those analyzed above. Microdissected trophoblasts were obtained separately from anchoring and branch villi. Ten serial sections (each section 10- $\mu \mathrm{m}$-thick) were prepared from each paraffin block, placed on a glass slide and stored at room temperature. An additional $5 \mu \mathrm{m}$ section, immediately adjacent to the $10 \mu \mathrm{m}$ sections, was used as a scout slide, and stained with hematoxylin and eosin (H\&E). Samples of anchoring- or branch-villous trophoblasts were obtained by microdissection with the aid of a fine-gauge needle, using the technique described by Tamura et al. (1998). Contamination of samples by decidual or stromal cells was avoided when possible. Dissected trophoblasts were transferred to a $0.5 \mathrm{ml}$ tube, and genomic DNA was extracted in $100 \mu \mathrm{L}$ Dexpat (Takara Shuzo).

DNA samples (10 $\mu$ l of Dexpat solution) were incubated with Hpa II as described above. A duplicate sample was incubated with $A f a I$ instead of Hpa II under the same conditions. After predigestion, DNA samples $(5 \mu \mathrm{l})$ were subjected to primary PCR in a total volume of $50 \mu \mathrm{l}$ containing $5 \mu \mathrm{l} 10 \times$ PCR buffer, including $15 \mathrm{mM} \mathrm{MgCl}_{2}$ (Takara Shuzo), $5 \mu \mathrm{l}$ dNTP (Takara Shuzo), $1 \mathrm{mM}$ forward primer (5'-CTGTTCCTGCCCGCGCGGTGT-3') (primer $1 \mathrm{~F}$ in
Fig. 1), $1 \mathrm{mM}$ reverse primer $\left(5^{\prime}\right.$-ACGCCTGTTACGTAAGCTCTG-3') (primer $1 \mathrm{R}$ in Fig. 1), and $0.625 \mathrm{U}$ DNA polymerase (Takara Shuzo), and PCR was performed under the same conditions as those described above. Aliquots $(3 \mu \mathrm{l})$ of the PCR products were reamplified with nested primers $(0.4 \mathrm{mM}$ each of primers $2 \mathrm{~F}$ and $2 \mathrm{R})$ under the same conditions, and aliquots $(5 \mu l)$ were digested with $B s t X I$ and visualized by ethidium bromide after agarose gel electrophoresis. The procedures were performed twice in separate experiments.

\section{Data interpretation}

On inactivated X-chromosomes, the $3^{\prime}$ cytosine of the CCGG Hpa II site in PGK is methylated, while the same site is unmethylated on active $\mathrm{X}$-chromosomes. Hpa II cleaves DNA at this site only when the $3^{\prime}$ cytosine is unmethylated. Incubating $\mathrm{Hpa} \mathrm{II}$ with DNA from tissues with random XCI results in approximately $50 \%$ digestion of both $P G K$ alleles, allowing both alleles to be amplified to similar levels. In tissues with preferential XCI, only the inactive X-chromosome escapes Hpa II digestion, and thus only DNA from the inactive allele is amplified during PCR.

$B s t X I$ cuts at a CCAN6TGG site within the amplified fragment of $P G K$, but as the Bst $X I$ site is polymorphic, some females will not carry the $B s t X I$ site on either chromosome, some will be homozygous for the Bst XI site, and some will be heterozygous. As shown in Fig. 1, a 530-bp band was observed for the allele without the Bst $X I$ site, and a 433-bp band was observed in alleles with the Bst XI site. Homozygous tissues generated either the 530- or 433-bp band, while heterozygous tissues showed both.

Each microdissected sample of trophoblasts was obtained from a restricted region of each anchoring or branch villi which was heterozygous for the PGK Bst XI polymorphism. If a monoclonal pattern (a single band of either 530 or $433 \mathrm{bp}$ ) was observed in the sample after Hpa II predigestion, the restricted region was determined to contain cells showing the same XCI status.

\section{Results}

Karyotypes of the villous chorion

In the 46 samples of villous chorion, 21 were determined to have a normal 46,XX karyotype.

Bst $X I$ polymorphism in $P G K$ in the branch villi and maternal peripheral blood

Of the 21 DNA samples of branch villi showing a normal female karyotype, 11 were heterozygous for the $P G K B s t$ $X I$ polymorphism. The parental origin of the trophoblastic alleles could be easily determined when the trophoblastic tissue was heterozygous and the maternal tissue was homozygous for the polymorphism. Of the 11 heterozygous 
samples, 6 were derived from women who were homozygous. The samples obtained from the six women were used for further analyses of XCI status in whole branch villi and in microdissected trophoblasts from anchoring or branch villi.

XCI status in the branch villous trophoblast

Samples which were heterozygous for the PGK Bst XI polymorphism and were derived from women homozygous for the polymorphism were used to study the parental origin of the inactive $\mathrm{X}$-chromosome. In five of six samples, the sizes of the two heterozygous band peaks after Hpa II predigestion differed much more than those after $A f a$ $I$ predigestion. Moreover, in the five samples with Hpa II predigestion, $\mathrm{X}^{\mathrm{M}}$-derived alleles showed smaller peak sizes than $\mathrm{X}^{\mathrm{P}}$-derived alleles, but the differences varied in degree. In the remaining sample, the sizes of the two heterozygous band peaks were similar. Figure 2 shows the peak patterns of two representative samples after $\mathrm{Hpa}$ II or Afa I predigestion; for comparison of the peak sizes of the six subject samples, Table 1 shows ratios of the mean peak heights and areas obtained from repeated experiments.

Fig. 2a $\mathbf{a}_{1}-\mathbf{b}_{2}$. Band peak patterns of representative samples of branch villous trophoblasts which were heterozygous for the Bst $X I$ polymorphism and derived from women homozygous for the polymorphism. $\mathbf{a}_{1}$, Sample no. 1 after Hpa II predigestion (number of sample refers to that shown in Table 1); $\mathbf{a}_{2}$ sample no. 1 after $A$ fa I predigestion; $\mathbf{b}_{\mathbf{1}}$ sample no. 2 after Hpa II predigestion; $\mathbf{b}_{2}$ sample no. 2 after $A f a$ $I$ predigestion. Arrows indicate band peaks which were derived from the maternal parent. Numerals indicate the molecular size (bp) of each peak. In a comparison of peak patterns between samples after Hpa II or Afa I predigestion, $\mathrm{X}^{\mathrm{M}}$-derived peaks were smaller than $\mathrm{X}^{\mathrm{P}}$-derived peaks in samples after Hpa II predigestion; a marked difference is observed in sample no. 1 , and a slight difference in sample no. 2
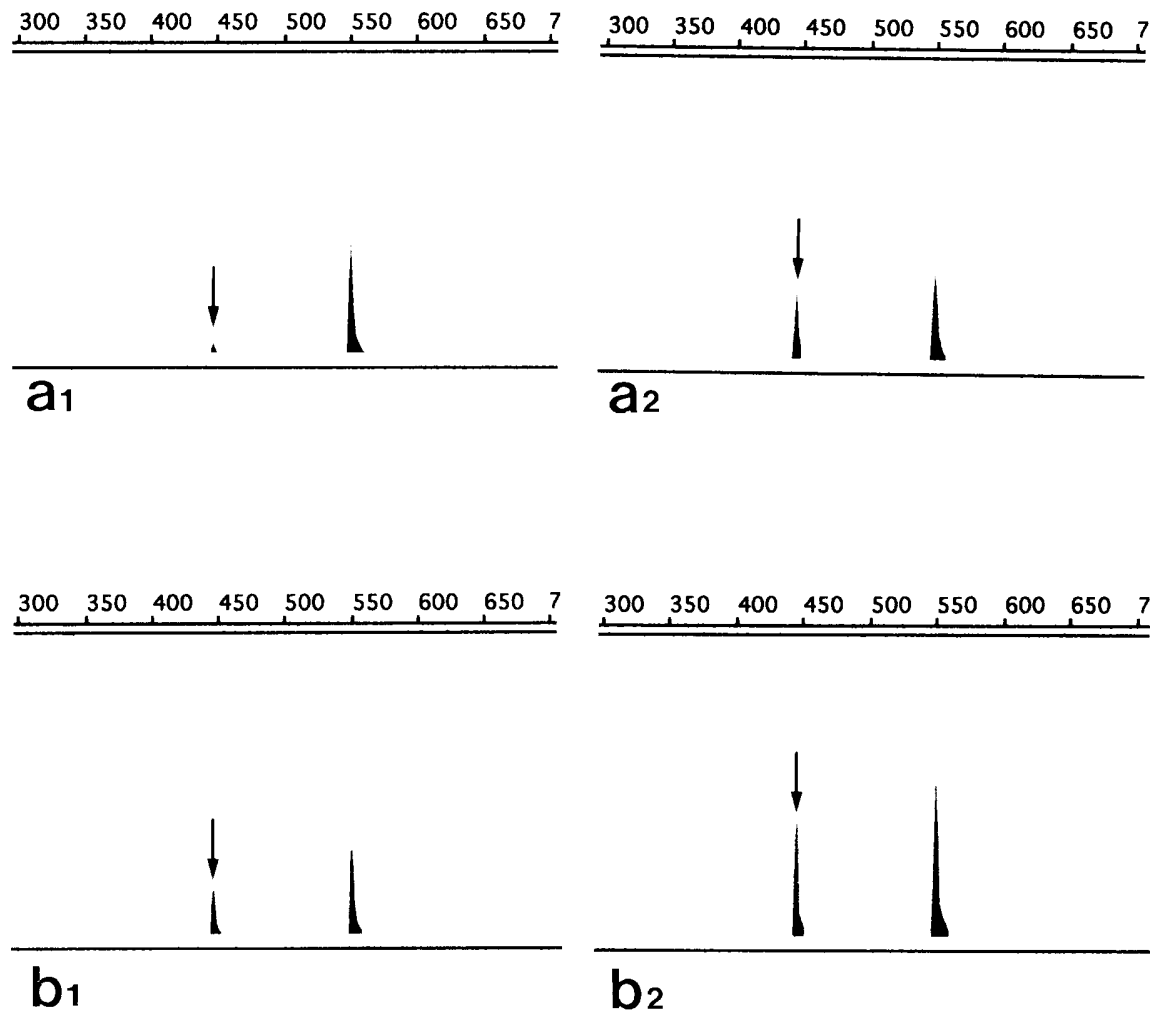

Table 1. Comparisons of band-peaks between $\mathrm{Hpa} I I$ and $A f a$ I predigestion ${ }^{\mathrm{a}}$

\begin{tabular}{|c|c|c|c|c|c|c|c|c|}
\hline \multirow{3}{*}{$\begin{array}{l}\text { No. of } \\
\text { sample }\end{array}$} & \multicolumn{4}{|c|}{ Peaks after $\mathrm{Hpa} I I$ digestion } & \multicolumn{4}{|c|}{ Peaks after $A f a I$ digestion } \\
\hline & \multicolumn{2}{|c|}{ Height } & \multicolumn{2}{|l|}{ Area } & \multicolumn{2}{|l|}{ Height } & \multicolumn{2}{|l|}{ Area } \\
\hline & $433 \mathrm{bp}$ & $530 \mathrm{bp}$ & $433 \mathrm{bp}$ & $530 \mathrm{bp}$ & $433 \mathrm{bp}$ & $530 \mathrm{bp}$ & $433 \mathrm{bp}$ & $530 \mathrm{bp}$ \\
\hline $1^{\mathrm{b}}$ & 1 & 9.0 & 1 & 13.0 & 1 & 1.3 & 1 & 1.7 \\
\hline $2^{b}$ & 1 & 1.8 & 1 & 2.3 & 1 & 1.4 & 1 & 1.8 \\
\hline $3^{c}$ & 5.5 & 1 & 4.1 & 1 & 1.1 & 1 & 0.8 & 1 \\
\hline $4^{c}$ & 3.5 & 1 & 3.0 & 1 & 0.7 & 1 & 0.6 & 1 \\
\hline $5^{c}$ & 2.6 & 1 & 2.0 & 1 & 0.9 & 1 & 0.7 & 1 \\
\hline $6^{c}$ & 1.0 & 1 & 0.8 & 1 & 0.8 & 1 & 0.7 & 1 \\
\hline
\end{tabular}

${ }^{a}$ Values are ratios when the size of the maternally derived allele is set at 1 . Each ratio is the mean value obtained from repeated experiments

${ }^{\mathrm{b}}$ Women were homozygous for the allele with the Bst XI site (ie, showing only the 433-bp band) in samples no. 1 and no. 2

${ }^{\mathrm{c}}$ Women were homozygous for the allele without the Bst XI site (ie, showing only the 530-bp band) in samples no. 3 through no. 6 


\section{Microdissection}

Thirty trophoblastic samples, each from a different anchoring villus, were obtained successfully by microdissection of the uterine contents of the same six women in whom XCI of the whole branch villi was analyzed. The trophoblastic mass was recognized by the specific morphology of being attached or adjacent to the decidua. Figure 3a,b illustrates the accuracy with which trophoblastic masses were dissected without contamination by other cells. Thirty-eight samples of the trophoblastic layer, each from a different branch villus, were also obtained by microdissection. Syncytiotrophoblasts line the outer surface of the branch villus as a single or multiple layer with cytotrophoblasts, forming a round or semiround shape that may include a few stromal cells. Figure $3 \mathrm{c}, \mathrm{d}$ shows that the trophoblastic layers were dissected with minimal contamination of stromal cells. Trophoblasts derived from the same anchoring or branch villus were successfully recovered from five or more sections. The number of microdissected trophoblast nuclei was calculated as approximately $400-700$ nuclei in each sample of anchoring villi, and as approximately 500-800 nuclei in each sample of branch villi.

XCI status in microdissected trophoblasts from anchoring or branch villi

Thirty samples of DNA from anchoring villi and 38 from branch villi were analyzed twice for XCI status, and there were no interassay differences of the PCR band patterns.
Figure 4 shows the band patterns after Hpa II or Afa I digestion of representative samples derived from anchoring and branch villi. After $A f a I$ digestion, a heterozygous pattern for the Bst XI polymorphism was observed in all DNA samples, with each of the two bands staining equally. In the 30 samples of anchoring villous trophoblasts, 19 showed only one band after Hpa II digestion, which suggested monoclonality of the microdissected tissue. Of those 19 samples, 13 showed the $\mathrm{X}^{\mathrm{P}}$ inactivation pattern, while 6 showed $\mathrm{X}^{\mathrm{M}}$ inactivation. In the 38 samples from branch villous trophoblasts, monoclonality was observed in 17 samples after Hpa II digestion; 14 showed $\mathrm{X}^{\mathrm{P}}$ inactivation, and 3 showed $\mathrm{X}^{\mathrm{M}}$ inactivation. In the remaining samples (11 from anchoring villous trophoblasts and 21 from branch villous trophoblasts), both bands were observed, which suggested the samples were polyclonal. These results are summarized in Table 2.

Table 2. X-chromosome inactivation status in clonality analyses of microdissected samples of trophoblasts

\begin{tabular}{lllll} 
& $\begin{array}{l}\text { Total } \\
\text { no. of } \\
\text { trophoblasts }\end{array}$ & \multicolumn{2}{l}{$\begin{array}{l}\text { No. of samples showing } \\
\text { preferential inactivation of }\end{array}$} \\
\cline { 3 - 5 } & samples & $\mathrm{X}^{\mathrm{P}}$ & $\mathrm{X}^{\mathrm{M}}$ & Neither \\
\hline Anchoring villi & 30 & 13 & 6 & 11 \\
Branch villi & 38 & 14 & 3 & 21
\end{tabular}

$\mathrm{X}^{\mathrm{P}}, \mathrm{X}$-chromosome of paternal origin; $\mathrm{X}^{\mathrm{M}}, \mathrm{X}$-chromosome of maternal origin
Fig. 3a-d. Photomicrographs of formalin-fixed sections of uterine contents a before and $\mathbf{b}$ after microdissection of the anchoring villus (arrowheads), and $\mathbf{c}$ before and $\mathbf{d}$ after microdissection of the branch villus (arrowheads). The trophoblastic mass of the villus was removed without contamination by other tissues. H\&E, $\times 200$
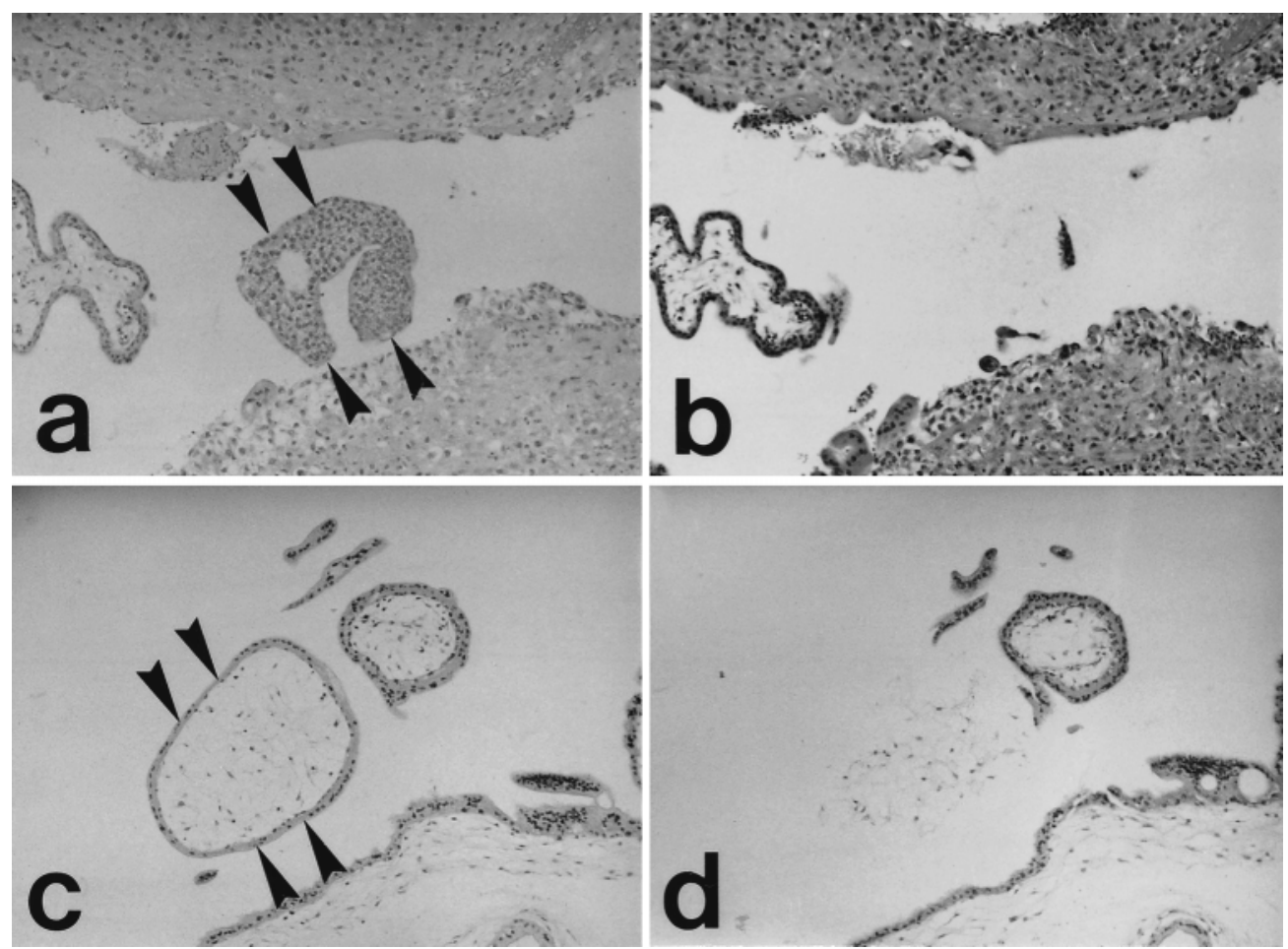

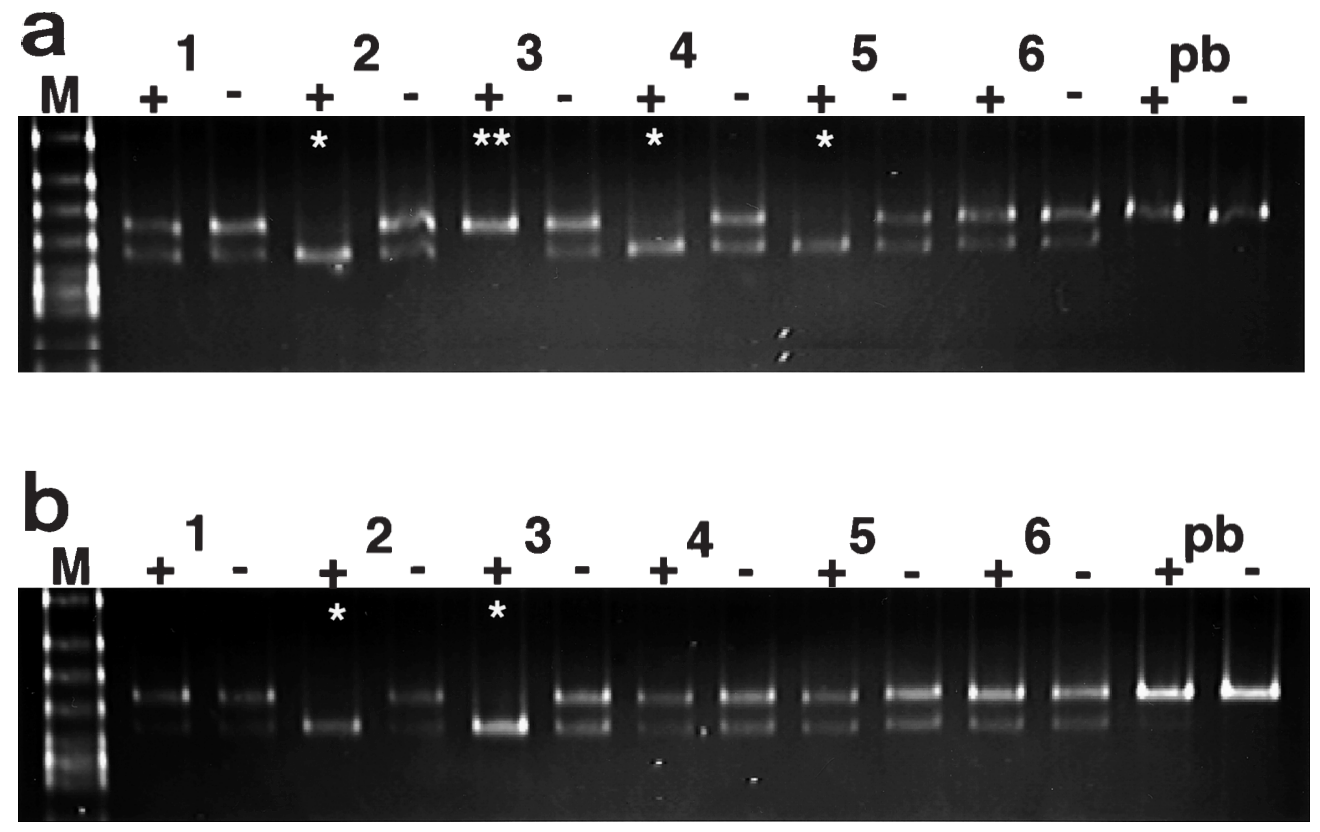

Fig. 4a,b. Band patterns of samples extracted from microdissected trophoblasts of an anchoring or branch villus (representative sample). a Trophoblasts from an anchoring villus, $\mathbf{b}$ trophoblasts from a branch villus. $p b$, Maternal peripheral blood. Lane $M$ shows molecular size markers $(\phi \mathrm{X} /$ Hinc II digest, Toyobo). Lanes $(+)$ and $(-)$ indicate that DNA was amplified with or without prior Hpa II digestion, respectively. The band pattern of pb shows a homozygous Bst XI polymor-

\section{Discussion}

Women with structurally aberrant X-chromosomes generally show a skewing of XCI because aberrant X-chromosomes (except for $\mathrm{X}$-chromosome translocations) are inactivated to compensate for $\mathrm{X}$-linked gene dosage (Therman and Patau 1974). Moreover, XCI skewing is common in fetuses or newborns with confined placental mosaicism (Lau et al. 1997). To examine the possibility of skewing caused by an X-chromosome aberration or placental mosaicism, we performed karyotypic analyses of branch villi, and only samples with a normal 46,XX karyotype were evaluated for the Bst XI polymorphism.

In five of the six samples from branch villi which were heterozygous for the PGK Bst XI polymorphism, the sizes of the $\mathrm{X}^{\mathrm{M}}$-derived band peaks were reduced compared with those of the $\mathrm{X}^{\mathrm{P}}$-derived band peaks. This result suggested that $\mathrm{X}^{\mathrm{P}}$ was predominantly inactivated in these samples. However, the differences between the two peak sizes of $\mathrm{X}^{\mathrm{P}}$ derived and $\mathrm{X}^{\mathrm{M}}$-derived alleles were slight (mainly 2- to 5fold, but in one sample nearly 10-fold) in five samples, and there was no difference in one sample. Therefore, using clonality analyses, we carried out detailed evaluation of $\mathrm{XCI}$ in microdissected trophoblasts from the same uterine contents. In microdissected samples, band patterns representing monoclonality caused by $\mathrm{X}^{\mathrm{P}}$ inactivation were more prevalent than those caused by $\mathrm{X}^{\mathrm{M}}$ inactivation, but almost half of the samples were polyclonal. Since the band patterns after digestion with Afa I demonstrated phism. Of the six anchoring villous trophoblast samples, three (indicated by single asterisks) show a band pattern indicating preferential Xchromosome of paternal origin $\left(\mathrm{X}^{\mathrm{P}}\right)$ inactivation and one (double asterisks) shows a band pattern indicating preferential $\mathrm{X}$-chromosome of maternal origin $\left(\mathrm{X}^{\mathrm{M}}\right)$ inactivation. In the six branch villous trophoblast samples, two (single asterisks) had preferential $\mathrm{X}^{\mathrm{P}}$ inactivation

that adequate numbers of trophoblasts could be obtained by microdissection from each villus, the Hpa II digest band patterns were deemed reliable for evaluation of clonality. Therefore, our finding suggests that a skewing (nonrandomness or asymmetry) of XCI exists in human trophoblastic tissues; however, the degree of skewing caused by predominant $\mathrm{X}^{\mathrm{P}}$ inactivation appears to be restricted. Preferential XCI has not been clearly defined concerning the percentage of cells with the same XCI status. As approximately $10 \%$ of normal women show a skewing of XCI as extreme as 90/10 (Naumova et al. 1996), we believe that the degree of skewing must be near or over $90 \%$ in tissues with preferential XCI. Therefore, the skewing observed in this study was too small to conclude that there is preferential $\mathrm{X}^{\mathrm{P}}$ inactivation in human trophoblasts. Our finding partly supports previous studies by Harrison and Warburton (1986), Harrison (1989), and Goto et al. (1997) with regard to positive skewing in trophoblasts, but the degree of skewing they proposed is considerably more than that shown here.

Chorionic villi develop from the trophectoderm of the blastocyst (Yoshida 1964), and primary villi undergo repetitive branching to form the villous chorion. In mice, $\mathrm{XCI}$ is nonrandom at the earliest points before differentiation to extra-embryonic tissues, so that $\mathrm{X}^{\mathrm{P}}$ is preferentially inactivated in $87 \%-88 \%$ of trophectoderm cells (Takagi et al. 1978; West et al. 1977). As the XCI state remains stable throughout multiple cell divisions (Heard et al. 1997; Goto and Monk 1998), 87\%-88\% of mouse trophoblasts will possibly show $\mathrm{X}^{\mathrm{P}}$ inactivation. Therefore, 
the degree of skewing in human trophoblasts appears low compared with that in mouse trophectoderm. As early onset of XCI may result in a mosaicism formed by bigger trophoblastic masses with the same clonality than late onset, the difference in the degree of skewing between mice and humans may be caused by different regulation of XIC (X inactivation center) transcription, which begins earlier in mice than in humans.

In the comparison of clonality between anchoring and branch villous trophoblasts, although the rates of monoclonal patterns indicating $\mathrm{X}^{\mathrm{P}}$ inactivation were not remarkably different, monoclonal patterns were observed more frequently in anchoring villi than in branch villi. Since the trophoblast samples obtained by microdissection from villous tissues were less than $100 \mu \mathrm{m}$ in thickness (or length), we speculate that monoclonal trophoblasts of the same XCI status may exist as masses of much less than $100 \mu \mathrm{m}$ in thickness (or length) in anchoring, as well as in branch villi. The sizes of monoclonal masses appear to be larger in branch villi than in anchoring villi, because monoclonal patterns were observed more frequently in anchoring villi. Moreover, based on the finding that monoclonal $\mathrm{X}^{\mathrm{P}}$ inactivation was observed more than $\mathrm{X}^{\mathrm{M}}$ inactivation, the trophoblastic masses of $\mathrm{X}^{\mathrm{P}}$ inactivation are possibly larger than those of $\mathrm{X}^{\mathrm{M}}$ inactivation.

Although there is a difference in the degree of skewing, skewing of XCI seems to be common in extra-embryonic tissues of humans and mice. The skewing of XCI is induced by resistance of $\mathrm{X}^{\mathrm{M}}$ and predisposition of $\mathrm{X}^{\mathrm{P}}$ to inactivation during early development. This parent-of-origin specific difference underlies genetic imprinting and probably occurs during gametogenesis through Xist expression (Heard et al. 1997; Goto and Monk 1998). However, the physiologic significance of skewing is not known. Therefore, further basic and clinical studies are necessary to examine its role in relation to reproductive physiology.

Acknowledgments We thank Keiko Abe for the preparation of thin sections, and Emiko Midorikawa for her assistance in karyotyping of branch villi.

\section{References}

Bamforth F, Machin G, Innes M (1996) X-chromosome inactivation is mostly random in placental tissues of female monozygotic twins and triplets. Am J Med Genet 61:209-215

Bird A (1986) CpG-rich islands and function of DNA methylation. Nature 321:209-213

Brown CJ, Ballabio A, Rupert JL, Lafreniere RG, Grompe M, Tonlorenzi R, Willard HF (1991) A gene from the region of the human $\mathrm{X}$ inactivation centre is expressed exclusively from the inactive X chromosome. Nature 349:38-44

Gilliland DG, Blanchard KL, Levy J, Perrin S, Bunn HF (1991) Clonality in myeloproliferative disorders: analysis by means of the polymerase chain reaction. Proc Natl Acad Sci USA 88:6848-6852

Goto T, Wright E, Monk M (1997) Paternal X-chromosome inactivation in human trophoblastic cells. Mol Hum Reprod 3:77-80

Goto T, Monk M (1998) Regulation of X-chromosome inactivation in development in mice and humans. Microbiol Mol Biol Rev 62:362-378

Harper MI, Fosten M, Monk M (1982) Preferential paternal X inactivation in extraembryonic tissues of early mouse embryos. J Embryol
Exp Morphol 67:127-135

Harrison KB (1989) X-chromosome inactivation in the human cytotrophoblast. Cytogenet Cell Genet 52:37-41

Harrison KB, Warburton D (1986) Preferential X-chromosome activity in human female placental tissues. Cytogenet Cell Genet 41:163-168

Heard E, Clerc P, Avner P (1997) X-chromosome inactivation in mammals. Ann Rev Genet 31:571-610

Kawai S, Imazeki F, Yokosuka O, Ohto M, Shiina S, Kato N, Omata M (1995) Clonality in hepatocellular carcinoma: analysis of methylation pattern of polymorphic X-chromosome-linked phosphoglycerate kinase gene in females. Hepatology 22:112-117

Kurman RJ, Main CS, Chen HC (1994) Intermediate trophoblast: a distinctive form of trophoblast with specific morphological, biochemical and functional features. Placenta 5:349-370

Lau AW, Brown CJ, Penaherrera M, Brown CJ, Penaherrera M, Langlois S, Kalousek DK, Robinson WP (1997) Skewed X-chromosome inactivation is common in fetuses or newborns associated with confined placental mosaicism. Am J Hum Genet 61:1353-1361

Looijenga LHJ, Gillis AJM, Verkerk AJMH, van Putten WLJ, Oosterhuis JW (1999) Heterogeneous X inactivation in trophoblastic cells of human full-term female placentas. Am J Hum Genet 64:1445-1452

Lyon MF (1961) Gene action in the X-chromosome of the mouse (Mus musculus L.). Nature 190:372-373

Michelson AM, Blake CCF, Evans ST, Orkin SH (1985) Structure of the human phosphoglycerate kinase gene and the intron-mediated evolution and dispersal of the nucleotide-binding domain. Proc Natl Acad Sci USA 82:6965-6969

Migeon BR, Do TT (1979) In search of non-random X inactivation: studies of fetal membranes heterozygous for glucose-6-phosphate dehydrogenase. Am J Hum Genet 31:581-585

Migeon BR, Wolf SF, Axelman J, Kaslow DC, Schmidt M (1985) Incomplete $\mathrm{X}$ chromosome dosage compensation in chorionic villi of human placenta. Proc Natl Acad Sci USA 82:3390-3394

Mohandas TK, Passage MB, Williams III JW, Sparkes RS, Yen PH, Shapiro LJ (1989) X-chromosome inactivation in cultured cells from human chorionic villi. Somat Cell Mol Genet 15:131-136

Monk M (1986) Methylation and the X chromosome. Bioessays 4:204208

Naumova AK, Plenge RM, Bird LM, Leppert M, Morgan K, Willard HF, Sapienza C (1996) Heritability of X chromosome inactivation phenotypes in a large family. Am J Hum Genet 58:1111-1119

Nomura S, Kaminishi M, Sugiyama K, Oohara T, Esumi H (1996) Clonal analysis of isolated single fundic and pyloric gland of stomach using X-linked polymorphism. Biochem Biophys Res Commun 226:385-390

Pfeifer GP, Tanguay RL, Steigerwald SD, Riggs AD (1990) In vivo footprint and methylation analysis by PCR-aided genomic sequencing: comparison of active and inactive $\mathrm{X}$ chromosomal DNA at the CpG island and promoter of human PGK-1. Gene Dev 4:12771288

Razin A, Riggs AD (1980) DNA methylation and gene function. Science 210:604-610

Ropers HH, Wolff G, Hitzeroth HW (1978) Preferential X inactivation in human placenta membranes: is the paternal $\mathrm{X}$ inactive in early embryonic development of female mammals? Hum Genet 43:265273

Seabright M (1971) A rapid banding technique for human chromosome. Lancet II:971-972

Shroyer KR, Gudlaugsson EG (1994) Analysis of clonality in archival tissues by polymerase chain reaction of PGK-1. Hum Pathol 25:287292

Takagi N, Wake N, Sasaki M (1978) Cytogenetic evidence for preferential inactivation of the paternally derived $\mathrm{X}$-chromosome in $\mathrm{XX}$ mouse blastocysts. Cytogenet Cell Genet 20:240-248

Tamura M, Fukaya T, Murakami T, Uehara S, Yajima A (1998) Analysis of clonality in human endometriotic cysts based on evaluation of $\mathrm{X}$ chromosome inactivation in archival formalin-fixed, paraffin-embedded tissue. Lab Invest 78:213-218

Tan SS, Williams EA, Tam PPL (1993) X-chromosome inactivation occurs at different times in different tissues of the post-implantation mouse embryo. Nature Genet 3:170-174

Therman E, Patau K (1974) Abnormal X chromosomes in man: origin, behavior and effects. Human Genetik 25:1-16

van Kamp HP, Jansen R, Willemze R, Fibbe WE, Landegent JE (1991) 
Studies on clonality by PCR analysis of the $P G K-1$ gene. Nucleic Acids Res 19:2794-2794

Vogelstein B, Fearon ER, Hamilton SR, Preisinger AC, Willard HF, Michelson AM, Riggs AD, Orkin SH (1987) Clonal analysis using recombinant DNA probes from the X-chromosome. Cancer Res 47:4806-4813
West JD, Frels WI, Chapman V, Papaioannou VE (1977) Preferential expression on the maternally derived $\mathrm{X}$ chromosome in the mouse yolk sac. Cell 12:873-882

Yoshida Y (1964) Ultrastructure and secretory function of the syncytial trophoblast of human placenta in early pregnancy. Exp Cell Res 34:305-317 